\title{
Integration of migrants as a way to diminish proneness to conflict in multinational communities
}

\author{
A. S. Matveevskaya', S. N. Pogodin ${ }^{2}$ \\ ${ }^{1}$ St. Petersburg State University, 7-9, Universitetskaya nab., St. Petersburg, 199034, Russian Federation \\ ${ }^{2}$ Peter the Great St. Petersburg Polytechnic University, \\ Politekhnicheskaya ul., 29, St. Petersburg, 195251, Russian Federation
}

For citation: Matveevskaya A.S., Pogodin S. N. Integration of migrants as a way to diminish proneness to conflict in multinational communities. Vestnik SPbSU. Philosophy and Conflict Studies, 2018, vol. 34, issue 1, pp. 108-114. https://doi.org/10.21638/11701/spbu17.2018.110

At the turn of 20 th and $21^{\text {st }}$ centuries, issues related to the integration of foreigners into the new environment are especially discussed by the public and politicians. It is not for nothing that political organizations and even parties that are strongly opposed to immigrants increasingly occupy the minds of Europeans. The purpose of this study is to assess the success of adaptation processes that allow immigrants to integrate into the socio-cultural environment, taking into account a complex set of natural, economic, political and socio-cultural factors. The successful integration of migrants into a new society can be determined when assessing the effective implementation of migrants' social potential. Methods of research are theoretical analysis of the impact of immigration processes on economic and social life. The work was carried out on the basis of studying and using fundamental Russian and foreign research of in the following scientific areas. The results of the research showed that the selected number of factors have a significant impact on the adaptation process of immigrants. Subjective factors are formed by immigrants and the objective factor is the perception of the adaptation of immigrants by the local population. It was found that the most important factors for successful integration of immigrants into society are not only training and working but also a number of social programs and practices conducted to promote the principles of tolerance and the diversity of society. Only a comprehensive approach to solving these problems can lead to the successful integration of migrants into the new society.

Keywords: immigration process, ethnic conflict, software integration of foreigners, social projects.

An increase in migration flows in the last fifty years has led to a great deal of cultural and ethnic variety in modern society.

When an individual or a group of people find themselves in a different social environment they need to adapt to a different culture and social organization. At this stage not only the social environment, but also the living environment, including geographic, ecological and climatic factors, undergo certain changes. Living conditions are also determined by a new political and economic situation.

Therefore, changing the place of living for a migrant means the necessity to adjust to new conditions: environmental, social, economic and ethnocultural. This process manifests itself as a biological adaptation (for instance, acclimatization), as well as a social and

() Санкт-Петербургский государственный университет, 2018 
psychological one. Adaptation to a set of multifaceted features of the new environment is usually complicated and not always successful.

Way back in ancient times the word "adaptation" (from Latin "adapto", to adapt) was used to define the adjustment of living beings to an environment. Charles Darwin included the notion "adaptation" into his theory of evolution showing the adaptive and selfadjusting properties of natural selection [1].

Stepping outside the bounds of biology, where the notion appeared for the first time, it began to be used in other sciences: medicine, psychology, demography, sociology, social history, anthropology, and others.

In demographic science "adaptation" is a kind of adjustment of an individual or a social group to a social environment [2]. The crucial component of adaptation in this respect is bridging the gap between the self-esteem and ambition of an individual and their abilities, as well as the current social environment, including the tendencies in the development of the environment and the given individuals. According to its tasks, in demography adaptation is studied on the basis of the whole population, families and migrant cohorts.

Social historians do research into the adaptive processes taking place among forced migrants. Scientists consider this issue in the light of the factors that caused forced displacement after the collapse of the USSR. They are especially interested in combining research into various countries, chronological periods, certain areas, integration of approaches, developing a typology of migrations and forms of adaptation.

At the beginning of the $20^{\text {th }}$ century, cross-cultural adaptation was widely studied in world science. On the basis of the culture of Russian settlers (the settlers in south Siberia) scientists studied a special local kind of Russian ethnos, without taking into account adaptive factors and assessing the degree of adaptation of the culture to a new environment. In this area of research the development of ethnic ecology in Russia became a great contribution [3].

This branch of science, being relatively new, emerged at the junction of ethnology as the science that deals with populations, and human ecology as the science that studies the relationship between people and nature, their social and cultural environment.

- The main tasks of ethnic ecology are as follows:

- studying traditional life-support systems in ethnic communities in their natural environment and social and cultural conditions, as well as the influence of ethnoecological interconnections on people's health and natural reproduction of ethnic groups,

- studying the particular ethno-cultural means ethnoses use their natural environment and have an impact on it.

In modern sociology "social adaptation" is regarded as a process and a result of active adjustment of an individual to a new social environment.

For an individual, social adaptation means a flexibly organized research activity in new conditions that exceeds the existing end form.

Yu. A. Miloslavsky states that the lesser individuality a person possesses the more social adaptation resembles adapting to a new social environment [4].

In the 1980s research into the theory and practice of professional adaptation was widely popular.

In recent years scientists have been more concerned with issues of social and economic adaptation of a population to changes in the economic system. 
At the beginning of the 1990s, Russian scientists started publishing papers devoted to the issues of the adaptation of forced migrants and refugees within the former Soviet Union.

It is worth noting that the role of the psychological factor is doubtless starting from the point when an individual becomes aware of the need to adapt to the changing living and working conditions up to an individual interpretation of the admissibility of a certain adaptive strategy. This explains a stable and fully justified interest of Russian and foreign scientists in studying the social adaptation of an individual within the framework of social psychology.

The given analysis of various approaches thus shows that a wide interpretation of the peculiarities of an individual adaptation process lies in the fact that in their lifetime individuals face the necessity to adapt to different elements of a social environment. These could be its social and psychological, cultural, professional, household and other features.

When forced migrants adapt to the new living conditions, the interconnection between two aspects can be certainly be traced: the personal adaptation of forced migrants to the new living conditions and the adaptation of the social environment (local people) to the personality of a forced migrant.

Many scientists researching the process of the "entrance" of migrants into a new social environment do not draw a line between the terms "integration" and "adaptation" of migrants. From our point of view, when considering external (international) migration one should differentiate between three levels of "entrance" of migrants into a new society [5].

The first stage of the establishment of migrants at a new place of living can be named the introduction process. This term can be used to speak about migrants who have arrived in a certain country in order to familiarize themselves with the living conditions there and to evaluate career opportunities for the first time, as well as people on short-term visits not having a wish to stay in the country for a long time.

The second level of the establishment of migrants consists in social adaptation comprising work-related, political, legal, cultural and spiritual aspects. The most acute issues of adaptation are the opportunities to find a good job and to contribute to the development of the local economy. Even more effort is required to achieve a level of establishment at which migrants become full-fledged members of the local community.

Integration is the third and most advanced level of "entrance" of migrants into a community, which, apparently, should be viewed as the end result of the adaptation of an individual or a social group to a society possessing different socio-cultural and ethnic characteristics. The speed and success of integration are important both for immigrants and local communities. It is integration that is able to guarantee due respect of rights and commitments of both parties, it determines the access of the former migrants to various kinds of services and the labor market and ensures social freedoms.

The process of the integration of migrants into a new society is significantly influenced by numerous factors, both objective and subjective. In many cases they determine the speed and nature of the adaptation process.

The cultural aspects of the establishment of migrants are the most versatile; however, the most difficult task is to identify their success. Due to occasional sudden population growth, the peculiarities of housekeeping among migrants, their traditional occupations and professional competences, as well as ethnos-related concepts, migration has the ability to change the cultural patterns and economic landscape of whole cities and regions [6]. 
This can result in an increase in productivity and, most importantly, a growth in cultural heritage and diversity. At the same time cultural differences, and especially religious ones, between migrants and local communities can affect such values as freedom of speech and religion. As a result, intolerance, discrimination and xenophobia can take place.

Up to a certain period of time it used to be thought that the integration of any person or group of people was merely a matter of time. It was also believed that the amount of time was determined by cultural differences between the host community and the native community of migrants.

At present, however, it has become clear that the context within which integration occurs and the conscious actions of migrants at individual and group levels play an important role. Moreover, it is not really evident that every next generation will be more successfully integrated - it is more of an undulated process of hopes, disillusionment and new hopes [7].

There is no unanimous integration pattern. Modern societies are a complex phenomenon: they consist of different groups and, as practice shows, migrants usually communicate with members of certain local communities more frequently than with others. It is their culture, speech peculiarities and values that migrants adopt.

Thus, for example, mutual adoption of lifestyle elements takes place as a result of interaction of previously autonomous groups. The tradition of Christmas trees was brought to the USA by German migrants, who were initially treated suspiciously by Americans, and having kebabs in the countryside in Russia is connected with Caucasian cuisine.

Migrants can be both deprived and affluent; nevertheless, they rarely live below the poverty line as it is difficult to move to another place of living without money. Migrants can be well-educated and uneducated. A typical well-educated migrant is a scientist who visits various research centers and conferences in different cities and countries or a university graduate from the USSR who could find themselves in the most remote areas owing to a special state program which forced them to do a state-provided job for a certain period of time after graduation.

Migrants can be internal and international but it is difficult to say who will find it more difficult to adapt in a new environment: a Russian person in Central Asia or an inhabitant of an Avarian village in Russian Dagestan who has moved to Moscow. This is connected with the fact that migrants may arrive from countries and regions with a culture which resembles that of the host community and they may not. Besides, migrants may be rural and urban, they may be easily identified and they may look practically the same as local people.

Thus, for instance, a very important category of "visible minorities" aimed at simplifying the integration of migrants appeared in Canadian legislation in 1996; this category refers to people with a great visual difference from the biggest part of the population. For example, Ukrainian migrants in Russia, being foreigners and sometimes speaking another language, are rarely faced with discrimination; they are seldom stopped by police since they look practically the same as local people. However, the same cannot be said about migrants from the Caucasus. The experience and practices used in various countries consist in social projects serving to alleviate the integration process for migrants. Such practices are aimed at helping migrants to cope with the difficulties they come up against in host communities and preparing the latter to receive migrants. Some of these practices are designed to satisfy the needs of certain categories of migrants, while others are supposed 
to raise tolerance in society thus making it easier for migrants to integrate. Some practices are regarded as successful and are applied in many countries whereas the efficiency of others still requires a proof.

Several European and Eurasian countries are running successful programs and practices in order to ensure efficient adaptation of migrants to local communities. These social projects, on the one hand, are aimed at helping migrants to resolve social issues and, on the other — to make the host community more tolerant.

One of the reasons why migrants find it difficult to integrate into a local community is the absence of a facility where they could communicate with local people. The social theatre established in Spain has become a place for real cultural interaction. Forty actors of various ethnic backgrounds on a regular basis speak about problems and difficult situations they have had when communicating with people belonging to various cultures. These discussions resulted in a performance shown on several stages in Barcelona.

The project of the social theater CasaAsia helped to fulfill several tasks at once [8]. On the one hand, people from different countries and of different cultural backgrounds became friends; on the other hand, the theatre performances themselves fostered crosscultural communication. It should be mentioned that the latter issue was brought to the attention of city authorities.

In Hungary a computer game about migrants was designed [9]. When someone visits the website of the game they have to choose a character - a representative of China, Ethiopia, Lebanon, Cote d'Ivoire or Nigeria. The goal of the game is to get to Hungary from a person's country of origin overcoming the difficulties real migrants have to face. The designers of the game used the data concerning the flow of migrants to the country and the real stories of migrants and their problems, so the game characters became composite characters based on dozens of real migrants. The translation of the game into English enabled people from other countries to join, although initially Hungarian schoolchildren were told about the game in their schools and it was played mainly by teenagers. The results of research undertaken by the popularizers of the game have proved not only a great interest among young people in the issue of migrants, but also some positive changes in the attitudes of teenagers to migrants. A social project the Living Library launched in Denmark in 2000 has become quite efficient and it is now popular in other countries and in Russia as well [10]. All roles of the participants of the Living Library are represented as "books", "librarians" and "readers".

People differing from the majority of others are "books". These may be representatives of various minorities including ethnic and religious, as well as migrants of other ethnicities. "Librarians", being in charge of the Living Library, have to look after communication. Other people wishing to socialize are "readers".

The purpose of the Living Library is to establish contacts between the majority and minority and to eliminate stereotypes which are characteristic in relation to people of another culture, religion or ethnicity. This practice helps to increase the level of tolerance and mutual understanding in a society.

Member countries of Eurasian Economic Community (EurAsEC) are also experienced in integrating migrants into a new community. Thus, for example, in Russia schoolchildren migrants draw and speak about themselves. The staff of the Anna Akhmatova Museum at the Fountain House and sociologists of the St Petersburg branch of the Higher School of Economics organized a few classes at schools for the children of migrants and 
their Russian-born classmates [11]. The children were asked to speak about their lives using various artistic means.

First-grade pupils drew contours of each other on large sheets of paper and then they drew themselves and glued up their figures. Older children $\left(2^{\text {nd }}-5^{\text {th }}\right.$ grade $)$ made installations among old suitcases. High school students filmed their interviews with the help of professionals exchanging their roles in turn (a star, a cameraman, a stylist, a film director). After that the works were exhibited at the Fountain House.

According to the teachers, the participation in the project stimulated the integration of migrants into school life and the exhibition was covered in the press and was widely discussed on the Internet.

\section{References}

1. Darwin Ch. Proiskhozhdenie vidov putem estestvennogo otbora [On the Origin of Species by Means of Natural Selection]. Leningrad, Nauka Publ., 1991. 234 p. (In Russian)

2. Glushkova V. G. (ed.) Demografiia [Demography], Study guide. Moscow, KnoRus Publ., 2004. 304 p. (In Russian)

3. Kozlov V.I. Etnicheskaia ekologiia: stanovlenie distsipliny $i$ istoriia problem [Ethnic Ecology: Establishment of the Discipline and the History of the Issue]. Moscow, Institut etnologii i antropologii RAN Publ., 1994. 230 p. (In Russian)

4. Miloslavsky Yu.A. Sotsial'naia adaptatsiia [Social Adaptation]. Rossiiskaia sotsiologicheskaia entsiklopediia [Russian Sociological Encyclopedia]. Ed. by G. V.Osipov. Moscow, NORMA-INFRA Publ., 1998. pp. 217-235. (In Russian)

5. Matveevskaya A.S. Teoreticheskie podkhody k izucheniiu aktual'nykh sotsial'no-ekonomicheskikh problem adaptatsii immigrantov [Theoretical approaches to studying actual socio-economic problems of immigrants adaptation]. Vestnik LGU im. A. S. Pushkina, 2010, vol. 6, no. 4, pp. 102-109. (In Russian)

6. Matveevskaya A.S., Pogodin S. N. Metodologicheskii podkhod k analizu integratsii immigrantov v stranakh Severnoi Evropy [Methodological approach to the analysis of immigrants' integration in countries of Northern Europe]. Nauchno-tekhnicheskie vedomosti SPbGPU im. Petra Velikogo, 2013, no. 179, pp. 124132. (In Russian)

7. Malakhov V.S. Integratsiia migrantov: Kontseptsii i praktiki [Integration of Migrants: Concepts and Practices]. Moscow, Fond «Liberal'naia Missiia», 2015. 272 p. (In Russian)

8. The official site of Casa Asia. Available at: http://www.casaasia.eu (accessed: 06.09.2017).

9. The official site of The intercultural innovation award. Available at: http://immigropoly.ittvagyunk. eu/ (accessed: 12.09.2017).

10. The official site of The Human Library Organization. Available at: http://humanlibrary.org (accessed: 17.10.2017).

11. Varshaver E. A. Dvadtsat' uspeshnykh praktik integratsii migrantov [Twenty Successful Practices of the Integration of Migrants]. Moscow, Moskovskii institut sotsial'no-kul'turnykh program Publ., 2014. 60 p. (In Russian)

Author's information:

Matveevskaya Anna S. _ PhD; annamatveevskaya@mail.ru

Pogodin Sergey N. — Doctor of History, Professor; pogodin56@mail.ru 


\title{
Интеграция мигрантов как способ уменьшения конфликтов в многонациональных сообществах
}

\author{
А. С. Матвеевская ${ }^{1}$, С. Н. Погодин ${ }^{2}$ \\ ${ }^{1}$ Санкт-Петербургский государственный университет, \\ Российская Федерация, 199034, Санкт-Петербург, Университетская наб., 7-9 \\ ${ }^{2}$ Санкт-Петербургский политехнический университет Петра Великого, \\ Российская Федерация, 195251, Санкт-Петербург, ул. Политехническая, 29
}

Для цитирования: Matveevskaya A.S., Pogodin S.N. Integration of migrants as a way to diminish proneness to conflict in multinational communities // Вестник СПбГУ. Философия и конфликтология. 2018. Т. 34. Вып. 1. С. 108-114. https://doi.org/10.21638/11701/spbu17.2018.110

На рубеже XX-XXI вв. вопросы, связанные с интеграцией иностранцев в новую среду, особо обсуждаются общественностью и политиками. Недаром умами европейцев все чаще завладевают политические организации и даже партии, которые настроены резко отрицательно в отношении иммигрантов. Вопросы, связанные с толерантностью местного населения к переселенцам, а также «включенности» иностранцев в жизнь социума делают данную проблему особенно актуальной. Целью данного исследования является оценка успешности процессов адаптации, позволяющих переселенцам интегрироваться в социально-культурную среду региона прибытия с учетом комплекса таких факторов, как природные, экономические, политические и социокультурные. Успешность интеграции мигрантов в новое общество может быть определена при оценке эффективной реализации мигрантами своего социального потенциала (знание языка, повышение уровня образования, участие в общественной жизни страны и др.). Методом исследования является теоретический анализ влияния иммиграционных процессов на экономическую и социальную жизнь общества. Работа проведена на основе изучения и использования фундаментальных отечественных и зарубежных исследователей по следующим научным направлениям: парадигмальные основания миграционных теорий; этнологические факторы адаптации вынужденных переселенцев и беженцев; влияние доминант миграционного пространства на модели поведения мигрантов. Результаты исследования показали, что выделенные факторы оказывают существенное влияние на процесс адаптации переселенцев. Субъективные факторы, формирующиеся со стороны иммигрантов, с одной стороны, и объективный фактор - восприятие адаптации иммигрантов местным населением, с другой стороны. Было выявлено, что важнейшими факторами успешной интеграции иммигрантов в общество являются не только обучение и работа, но также ряд социальных программ и практик, проводимых с целью распространения принципов толерантности и многообразия общества. Только комплексный подход к решению данных проблем может привести к успешной интеграции мигрантов в новое общество.

Ключевые слова: иммиграционный процесс, этнический конфликт, интеграция мигрантов, социальные проекты, мультинациональные сообщества, мигранты.

Контактная информация:

Матвеевская Анна Сергеевна — канд. геогр. наук; annamatveevskaya@mail.ru

Погодин Сергей Николаевич - д-р ист. наук; pogodin56@mail.ru 